\title{
Mucosal Substitutes for Periodontal Soft Tissue Regeneration
}

\section{Swati Gupta ${ }^{\text {** }}$ Pratibha PK², Richa Gupta ${ }^{3}$}

${ }^{1} M D S$, Department of Periodontics, Manipal College of Dental Sciences, Manipal, Karnataka, India

${ }^{2} \mathrm{MDS}$, Additional Professor, Department of Periodontics, Manipal College of Dental Sciences, Manipal, Karnataka, India

${ }^{3} \mathrm{MD}$, Pool Officer, Department of Anatomy, PGIMER, Chandigarh, India

\begin{abstract}
Periodontal plastic surgery would be defined as the surgical procedures performed to prevent or correct anatomic developmental, and traumatic or disease induced defects of the gingiva, alveolar mucosa or bone. The introduction of oral mucosal equivalents also called as mucosal substitutes or mucosal fillers, composed of the structured triad of scaffold, cells and signaling molecules could be considered the essence or a culmination of the notion of periodontal regeneration. For the purpose of soft tissue augmentation, various mucogingival surgical procedures that are usually performed are: connective tissue grafts (gold standard) and its modifications, lateral pedicle flap, free gingival grafts, semilunar flaps, coronally positioned flaps. Several mucosal substitutes have been fabricated and tried with varying results. Tissue engineered mucosal constructs owe their origin to the treatment of ulcers, diabetic foot and burns. There is an increasing interest in the field of dentistry too. Mucosal substitutes are made of cell sources that have not caused acute and chronic tissue reaction and have self-renewal properties that can re-grow and differentiate to a new tissue. With all the advantages of reproducible tissue engineering technologies, these mucosal substitutes/ oral mucosal equivalents appear to be the imminent hope for tissue repair, replacement or regeneration in regenerative medicine in the treatment of lost tissues, impaired functions and soft tissue defects that are caused by congenital abnormalities, trauma, diseases or aging processes.
\end{abstract}

Keywords: Periodontal; Mucogingival surgery; Soft tissue augmentation; Mucosal substitutes; Mucosal constructs

\section{Introduction}

Tissue engineering or regenerative medicine has been defined as an interdisciplinary field that applies the principles of engineering and life sciences that contributes towards the development of biological substitutes for the repair or regeneration of tissue or organ function $[1,2]$. The concept of tissue engineered constructs has led to a paradigm shift in treatment options from using synthetic implants and tissue grafts to a tissue engineering approach that uses degradable porous material scaffolds integrated with biological cells or molecules to regenerate tissues. The introduction of oral mucosal equivalents also called as mucosal substitutes or mucosal fillers, composed of the structured triad of scaffold, cells and signaling molecules could be considered the culmination of the notion of periodontal regeneration.

\section{Background}

Soft tissue defects that are of concern and usually require treatment are:

a) Gingival augmentation

b) Root coverage

c) Correction of mucosal defects at implants

d) Removal of aberrant frenulum

e) Augmentation of edentulous ridge

f) Prevention of ridge collapse associated with tooth extraction

g) Crown lengthening

h) Gingival preservation at ectopic tooth eruption site

The most common and prevalent issues faced today are those of gingival recession and inadequate width of attached gingiva. The presence of an adequate width of attached gingiva is a prerequisite for a healthy gingiva. An adequate width varies for each individual and an inadequate width is a complicating factor in periodontal therapy. Gingival recession is defined as the apical migration of the marginal gingiva, creating esthetic as well as pathological complications.

For the purpose of soft tissue augmentation, the various mucogingival surgical procedures that are usually performed are connective tissue graft and its modifications, lateral pedicle flap, free gingival grafts, semilunar flaps and coronally positioned flaps. However, the disadvantages like second site morbidity and patient discomfort with these procedures have led us towards the use of mucosal substitutes.

\section{Mucosal Substitutes/Scaffolds}

Mucosal substitutes or scaffolds have following features:

- They serve as a temporary supporting structure (extracellular matrix), the initial architecture, on which the cells can grow three-dimensionally into the desired tissue.

- They provide the environment needed for cellular growth and differentiation.

- They provide the strength to withstand mechanical stress and guide their growth

- They are biodegradable and degrade at the same rate as the tissue regenerates to be optimally replaced by the host tissue.

These scaffolds could be categorized as:

a) Naturally Derived Scaffolds: Acellular Dermis, amniotic membrane

b) Fibroblast-populated Skin Substitutes: Dermagraft ${ }^{\mathrm{TM}}$, Apligraf $^{\mathrm{TM}}$, Orcel ${ }^{\mathrm{TM}}$, Polyactive ${ }^{\mathrm{TM}}$, Hyalograf $3 \mathrm{D}^{\mathrm{TM}}$

c) Gelatin-based Scaffolds

d) Collagen-based Scaffolds

*Corresponding author: Dr. Swati Gupta, MDS, Periodontal Consultant, House No. 3233, Sector 37 D, Chandigarh-160036, India, Tel: +91-8968340612; E-mail: swati.gup9@gmail.com

Received July 15, 2015; Accepted August 14, 2015; Published August 24, 2015

Citation: Gupta S, Pratibha PK, Gupta R (2015) Mucosal Substitutes for Periodontal Soft Tissue Regeneration. Dentistry 5: 327. doi:10.4172/2161-1122.1000327

Copyright: $\odot 2015$ Gupta S, et al. This is an open-access article distributed under the terms of the Creative Commons Attribution License, which permits unrestricted use, distribution, and reproduction in any medium, provided the original author and source are credited. 
e) Fibrin-based Scaffolds

f) Hybrid Scaffolds: Skin substituteS based on a combination of synthetic and natural materials.

g) Synthetic Scaffolds: Polyethylene terephtalate membranes (PET membranes), Porous polylactic glycolic acid (PLGA)

Several mucosal substitutes have been fabricated and tried with varying results, are described below.

\section{Mucograft prototype (Geistlich Mucograft')}

It is a $3 \mathrm{D}$ collagen matrix specifically designed for soft tissue regenerative purposes. It consists of two structures- the compact macro-structure provides stability and favors open healing whereas the spongy micro-structure supports blood clot stabilization and the in growth of soft tissue cells. This new collagen matrix (CM) aimed to increase keratinized gingiva/mucosa, when compared with the free connective tissue graft (CTG), and has been tested by many randomized longitudinal parallel controlled clinical trials. Only few clinical trials have been conducted comparing CM with CTG. All the trials have suggested the unique properties of mucograft for soft tissue augmentation with added advantages of lower patient morbidity and reduced surgery time [3-5]. However one study has indicated that CM results in more tissue contraction (67\%) as compared to CTG $(60 \%)$ [4] (Table 1).

\section{Collagen matrix 10826 (bi-layered collagen nano-structured membrane prototype)}

This is a collagen matrix of porcine origin fabricated by Geistlich Pharma AG (Switzerland) To evaluate fundamental cell functions, such as adhesion, IL-6 production and proliferation of human gingival keratinocytes cultured, a study was performed on this newly engineered collagen. Functional tests revealed that keratinocytes adhered to CM-10826 and up-regulated their basal IL-6 production. The type of keratinocytes used expressed cytokeratin 14. Proliferation experiments demonstrated that the best cellular response was observed in the presence of Collagen I, the main component of CM-10826. No undesired effects were observed as regards for keratinocyte viability, morphology or differentiation.

The results demonstrated that CM-10826 has a favorable biological effect on the in vitro response of gingival keratinocytes in terms of IL-6 production, cell growth and adhesion, thus encouraging a possible use of this collagen membrane as a tissue which, alone, may substitute for autologous gingival grafts thereby overcoming the limitations of autologous tissue [5]. No in vivo studies have been performed with this substitute.

\section{Matriderm}

Matriderm by Medskin solutions is of bovine origin, consists of $1 \mathrm{~mm}$-thick structurally intact native collagen matrix coated with a-elastin hydrolysate from the ligament, freeze-dried and non-crosslinked. This scaffold was introduced to treat deep and full-thickness burns in the field of dermatology. It provided the advantages of esthetics and suitable color match, no blisters and hypertrophic scar formation at the surgical site. Owing to its properties of generation of engraftable skin, recently it has been described as a suitable scaffold for tissue engineering. Matriderm has been shown to be suitable for the ex vivo growth of gingival tissue cells and is proposed as a scaffold with possible applications in periodontal therapy [6]. This product is widely used for skin grafting; however studies regarding the in vivo use of Matriderm are not available.

\section{Human amniotic membrane}

The amniotic membrane (AM) is considered an important potential source for scaffolding material. The AM represents the innermost layer of the placenta and is composed of a single epithelial layer, a thick basement membrane and an avascular stroma. The special structure and biological viability of the AM allows it to be an ideal candidate for creating scaffolds used in Tissue Engineering (TE). Epithelial cells derived from the AM have the advantages of stem cells, thus are a more suitable source of cells for TE than stem cells. The extracellular matrix components of the basement membrane of the AM create an almost native scaffold for cell seeding in TE. Various case reports have observed that amnion membrane has the properties of antibacterial, biocompatibility, color match, no scar formation and many more favoring new epithelium formation [7-9]. Thus, it has been suggested that amnion membrane is a suitable alternative to free gingival grafts for root coverage and soft tissue enhancement (Table 2).

\section{Emdogain}

Emdogain or Enamel matrix derivative (EMD) developed by Straumann is an extract of porcine fetal tooth material used to bio mimetically stimulate the soft and hard tissues surrounding teeth to regrow (in a process known as regeneration) following tissue destruction. A commercially prepared and purified extract of enamel matrix proteins, EMD is composed primarily of amelogenin and has been shown to promote PDL fibroblast proliferation and growth [10]. The effects of Emdogain are thought to be the induction of proliferation, migration, adhesion, mineralization and differentiation of cells in periodontal tissue. EMD mimics normal root development by stimulating release of autocrine growth factors from periodontal ligament undifferentiated mesenchymal cells [11]. It has been shown to promote periodontal wound healing and/or regeneration when applied to tooth root surfaces in soft tissue dehiscence models. EMD application has been found to be an effective alternative to achieve root coverage together with a gain in height of keratinized gingiva, in interdental papilla reconstruction and new cementum formation [1214] (Table 3).

\section{Ex vivo produced oral mucosa equivalent (EVPOME)}

In vitro cultured equivalents have become very promising in the field of oral and periodontal surgery. EVPOME was made from primary human oral keratinocytes, harvested from palatal keratinized mucosa. It was developed by University of Michigan. This was expanded in vitro in an environment free of serum, transformed irradiated xenogeneic feeder cells, and pituitary extract in a defined culture medium [15]. After sufficient oral keratinocytes were produced, they were seeded onto AlloDerm (an acellular dermal matrix; LifeCell) to produce a full-thickness EVPOME suitable for intraoral grafting. This whole procedure took a month. The EVPOME clinically has showed changes indicating vascular ingrowth and cytological evidence of the persistence of grafted cultured keratinocytes on the surface. An in vivo study conducted to assess the efficacy and safety of the grafted EVPOME in producing a keratinized mucosal surface epithelium concluded that it has the capability to augment keratinized tissue around the teeth [16].

\section{Fibroblast derived dermal substitute (HF-DDS)}

Cultured epithelium fabricated with living mucosal cells and epithelial sheets prepared by cultivating fibroblasts onto scaffold to have been used successfully for gingival augmentation. Human fibroblast-derived dermal substitute (HF-DDS) is an example of a tissue engineered construct designed to increase the amount of 
Citation: Gupta S, Pratibha PK, Gupta R (2015) Mucosal Substitutes for Periodontal Soft Tissue Regeneration. Dentistry 5: 327. doi:10.4172/21611122.1000327

\begin{tabular}{|c|c|c|c|c|}
\hline Investigators & Study design & Method & Results & Conclusion \\
\hline Sanz et al. [3] & $\begin{array}{l}\text { Randomized control } \\
\text { trial }\end{array}$ & $\begin{array}{l}20 \text { patients with at least one location } \\
\text { with minimal keratinized tissue }(41 \\
\mathrm{mm}) \text {, older than } 20 \text { years of age. } \\
\text { Test group: } \\
\text { Collagen matrix }(\mathrm{CM}) \text { aimed to increase } \\
\text { keratinized gingiva/mucosa, } \\
\text { Control group: free connective tissue } \\
\text { graft (CTG) }\end{array}$ & $\begin{array}{l}\text { Morbidity was assessed pre-operatively at } 1,3 \\
\text { and } 6 \text { months. At } 6 \text { months, the CTG attained a } \\
\text { mean width of keratinized tissue of } 2.6(0.9) \mathrm{mm} \text {, } \\
\text { while the CM was } 2.5(0.9) \mathrm{mm} \\
\mathrm{CM} \text { group had a significantly lower patient } \\
\text { morbidity (pain and medication intake) as well as } \\
\text { reduced surgery time }\end{array}$ & $\begin{array}{l}\text { CM, when used as a soft tissue } \\
\text { substitute was as effective and } \\
\text { predictable as the CTG for } \\
\text { attaining a band of keratinized } \\
\text { tissue }\end{array}$ \\
\hline Rotundo et al. [4] & Case report & $\begin{array}{l}\text { Three women showing } 11 \text { maxillary } \\
\text { gingival recessions were treated by } \\
\text { means of the envelope flap technique } \\
\text { associated with a novel collagen matrix }\end{array}$ & $\begin{array}{l}\text { At } 1 \text { year, complete root coverage was achieved } \\
\text { in } 9 \text { treated sites, with a mean keratinized tissue } \\
\text { width of } 3.1 \mathrm{~mm} \text {, complete resolution of dental } \\
\text { hypersensitivity, and a high level of esthetic } \\
\text { satisfaction. }\end{array}$ & $\begin{array}{l}\text { Mucograft when used as } \\
\text { substitute for CTG, has proved } \\
\text { to be ideal for achieving root } \\
\text { coverage }\end{array}$ \\
\hline Morelli et al. [20] & $\begin{array}{l}\text { Prospective split- } \\
\text { mouth pilot case } \\
\text { series }\end{array}$ & $\begin{array}{l}5 \text { patients with inadequate amounts of } \\
\text { keratinized attached gingiva bilaterally } \\
\text { in the posterior mandible, treated with } \\
\text { Autogenous gingival graft (AGG) on } \\
\text { one side and with CM on other }\end{array}$ & $\begin{array}{l}\text { Statistically significant increases in attached } \\
\text { gingiva at all test (CM) and control (AGG) sites. } \\
\text { The CM sites at } 12 \text { months blended well with } \\
\text { surrounding tissues, while the AGG sites were } \\
\text { morphologically dissimilar to the adjacent } \\
\text { areas. Histologic similarity between CM and } \\
\text { AGG treatments, with all sites exhibiting mature } \\
\text { connective tissue covered by keratinized } \\
\text { epithelium. }\end{array}$ & $\begin{array}{l}\mathrm{CM} \text { is an effective substitute for } \\
\text { increasing attached gingiva }\end{array}$ \\
\hline
\end{tabular}

Table 1: Mucograft prototype.

\begin{tabular}{|c|c|c|c|c|}
\hline Investigators & Study design & Method & Results & Conclusion \\
\hline Shah et al. [7] & Case report & $\begin{array}{l}\text { Amnion membrane was used in Millers } \\
\text { Class II recession in relation to the } \\
\text { tooth number \#14 measuring } 3 \mathrm{~mm} \\
\text { vertically and horizontally. The patient } \\
\text { had a thin gingival biotype }\end{array}$ & $\begin{array}{l}\text { Complete root coverage, with excellent } \\
\text { tissue contour and color blend, was } \\
\text { observed over the period of follow-up. } \\
\text { Also, the tissue biotype was observed } \\
\text { to be enhanced }\end{array}$ & $\begin{array}{l}\text { Amnion allograft may provide } \\
\text { an alternative to other } \\
\text { conventional methods of } \\
\text { treating gingival recession. }\end{array}$ \\
\hline Shetty et al. [9] & $\begin{array}{l}\text { Case report-split mouth } \\
\text { study }\end{array}$ & $\begin{array}{l}\text { Bilateral multiple adjacent gingival } \\
\text { recessions treated with a combined } \\
\text { coronally advanced flap (CAF) PrF and } \\
\text { CAF amniotic membrane }\end{array}$ & $\begin{array}{l}\text { Both the treatment procedures showed } \\
100 \% \text { root coverage and increased } \\
\text { gingival biotype. However, the amniotic } \\
\text { membrane-treated sites showed more } \\
\text { stable results than the PrF-treated sites } \\
\text { at the end of the seventh month. }\end{array}$ & $\begin{array}{l}\text { Use of amniotic membrane } \\
\text { as a novel approach to } \\
\text { root coverage is more } \\
\text { advantageous than PrF }\end{array}$ \\
\hline Ghahroudi et al. [8] & $\begin{array}{l}\text { Double-blind, } \\
\text { randomized, controlled } \\
\text { study }\end{array}$ & $\begin{array}{l}\text { Control group, } n=29 \text { recessions in } 10 \\
\text { patients: coronally displaced flap plus } \\
\text { connective tissue graft } \\
\text { Test group, } n=42 \text { recessions in } 12 \\
\text { patients: coronally displaced flap plus } \\
\text { amnion allograft. }\end{array}$ & $\begin{array}{l}\text { Changes in depth and width of } \\
\text { recessions, in gingival width, level of } \\
\text { attachment and probing depths after } 6 \\
\text { months were statistically significant in } \\
\text { the test group }\end{array}$ & $\begin{array}{l}\text { Amnion allograft might be } \\
\text { a suitable alternative to } \\
\text { connective tissue graft in } \\
\text { procedures to cover denuded } \\
\text { root surfaces and can reduce } \\
\text { recession depth. }\end{array}$ \\
\hline
\end{tabular}

Table 2: Human amniotic membrane.

keratinized tissue around teeth that do not require root coverage. The tissue engineered HF-DDS graft has been found to be safe and capable of generating keratinized tissue without the morbidity and potential clinical difficulties associated with donor site surgery [17-19] (Table 4).

\section{$\operatorname{CelTx}^{(\mathrm{TM})}$ (Organogenesis)}

CelTx $^{(\mathrm{TM})}$ is a living cellular construct comprised of human fibroblasts, keratinocytes and extracellular matrix proteins. The living cells found in CelTx produce a wide array of growth factors and cytokines that in turn stimulate the patient's own cells to regenerate new tissue that is clinically significant and aesthetically appealing.

The temporal expression of angiogenic biomarkers during wound healing of soft tissue reconstructive procedures was investigated by comparing living cellular constructs (LCC) with autogenous free gingival grafts. 44 human participants bilaterally lacking sufficient zones of attached keratinized gingiva were randomly assigned to soft tissue surgery plus either LCC or autograft. Wound fluid samples were collected at baseline and weeks 1,2, 3, and 4 post-operatively and analyzed for a panel of angiogenic biomarkers: angiogenin (ANG), angiostatin (ANT), PDGF-BB, VEGF, FGF-2, IL-8, TIMP-1, TIMP2, GM-CSF, and IP-10. Results demonstrated a significant increase in expression of ANT, PDGF-BB, VEGF, FGF-2, and IL-8 for the LCC group over the autograft group at the early stages of wound repair. Although angiogenic biomarkers were modestly elevated for the LCC group, no clinical correlation with wound healing was found. This investigation demonstrated that, during early wound-healing events, expression of angiogenic-related biomarkers is up-regulated in sites treated with LCC compared with autogenous free gingival grafts, which may provide a safe and effective alternative for regenerating intra-oral soft tissues [20].

If approved, CelTx will be the first, living cell-based technology that is FDA approved for use in the dental market.

\section{GINTUIT $^{\mathrm{rn}}$}

GINTUIT is an allogeneic cellularized scaffold product, a thin cellular sheet made of human fibroblasts, keratinocytes, human extracellular matrix proteins and bovine collagen developed by Organogenesis Company. FDA has approved this cell-based product for generating new and aesthetically appealing oral tissues.

Organogenesis completed a multi-center, randomized, pivotal clinical trial in 2012 to determine the efficacy and safety of GINTUIT to regenerate oral soft tissue in patients with gingival recession. The GINTUIT-treated sites generated a clinically significant amount of 
Citation: Gupta S, Pratibha PK, Gupta R (2015) Mucosal Substitutes for Periodontal Soft Tissue Regeneration. Dentistry 5: 327. doi:10.4172/21611122.1000327

Page 4 of 6

\begin{tabular}{|c|c|c|c|c|}
\hline Investigators & Study design & Method & Results & Conclusion \\
\hline Jaiswal et al. [12] & $\begin{array}{l}\text { Randomized case } \\
\text { control study }\end{array}$ & $\begin{array}{l}\text { Twenty patients with a total of } 46 \text { gingival } \\
\text { recession defects, } \\
\text { Test group: } 10 \text { patients with } 22 \text { recession defects } \\
\text { treated with Emdogain with CPF } \\
\text { Control group: } 10 \text { patients with } 24 \text { gingival } \\
\text { recession defects, was treated with } 24 \% \text { EDTA } \\
\text { with CPF }\end{array}$ & $\begin{array}{l}\text { Emdogain gel resulted in a statistically } \\
\text { significant increase in root coverage, gain } \\
\text { in the clinical attachment level (CAL), and } \\
\text { probing pocket depth (PPD) reduction. } \\
\text { No difference in gain of width of gingiva in } \\
\text { both groups }\end{array}$ & $\begin{array}{l}\text { Emdogain is an effective } \\
\text { alternative for root } \\
\text { coverage procedures }\end{array}$ \\
\hline Berlucchi et al. [13] & $\begin{array}{l}\text { Randomized case } \\
\text { control study }\end{array}$ & $\begin{array}{l}13 \text { recessions, Emdogain was used in } \\
\text { combination with a coronally advanced flap } \\
\text { (CAF+EMD group). } \\
\text { In the other } 13 \text { recessions, Emdogain and the } \\
\text { flap were used in combination with a subepithelial } \\
\text { connective tissue graft (CAF+CTG+EMD group). }\end{array}$ & $\begin{array}{l}\text { CAF+CTG+EMD group displayed good } \\
\text { clinical results in terms of root coverage, } \\
\text { increased width of keratinized gingiva, }\end{array}$ & $\begin{array}{l}\text { EMD has appreciable } \\
\text { wound healing and } \\
\text { regenerative properties. }\end{array}$ \\
\hline Hägewald et al. [14] & $\begin{array}{l}\text { Blinded, split-mouth, } \\
\text { placebo-controlled and } \\
\text { randomized design. }\end{array}$ & $\begin{array}{l}30 \text { patients, aged } 22-62 \text { years, with } 2 \text { paired } \\
\text { buccal recession defects of at least } 3 \mathrm{~mm} \text {. } \\
\text { Test group: EMD+ CPF } \\
\text { Control group: placebo (propylene glycol alginate) } \\
+ \text { CPF }\end{array}$ & $\begin{array}{l}\text { Recession width }(P=0.027) \text { and probing } \\
\text { pocket depth }(P=0.046) \text { exhibiting a higher } \\
\text { reduction in the EMD group. } \\
\text { Height of keratinized tissue, probing } \\
\text { attachment level, probing pocket depth and } \\
\text { alveolar bone level were not statistically } \\
\text { different in both the groups }\end{array}$ & $\begin{array}{l}\text { EMD has better long } \\
\text { term results }\end{array}$ \\
\hline
\end{tabular}

Table 3: Emdogain

\begin{tabular}{|c|c|c|c|c|}
\hline Investigators & Study desig & Method & Results & Conclusion \\
\hline Mohammadi et al. [17] & Case report & $\begin{array}{l}\text { Tissue-engineered gingival graft (HF- } \\
\text { DDS) was used for regenerating facial } \\
\text { gingiva around an implant at lower left first } \\
\text { premolar area with insufficient attached } \\
\text { gingiva. }\end{array}$ & $\begin{array}{l}\text { The histological features demonstrated } \\
\text { a fully keratinized tissue supported by } \\
\text { dense connective tissue. } \\
\text { The width of keratinized gingiva and } \\
\text { attached gingiva was more at } 3 \text { months } \\
\text { compared to baseline. }\end{array}$ & $\begin{array}{l}\text { The tissue engineered gingival graft is } \\
\text { safe and capable of generating keratinized } \\
\text { tissue without the morbidity and potential } \\
\text { clinical difficulties associated with donor site } \\
\text { surgery. }\end{array}$ \\
\hline Wilson et al. [18] & $\begin{array}{l}\text { Split mouth } \\
\text { case control } \\
\text { clinical trial }\end{array}$ & $\begin{array}{l}\text { Thirteen patients. } \\
\text { Each patient had Miller Class I or II } \\
\text { bilateral facial recession defects } \geq 3 \mathrm{~mm} \text { on } \\
\text { two non-adjacent teeth. } \\
\text { The test tooth received an HF-DDS graft } \\
\text { Control site: CTG was placed } \\
\text { Eight of the HF-DDS sites received a } \\
\text { single thickness of material; five received a } \\
\text { double thickness. }\end{array}$ & $\begin{array}{l}\text { Amount of root coverage and Width of } \\
\text { keratinized tissues was slightly greater } \\
\text { in control group. }\end{array}$ & $\begin{array}{l}\text { Human fibroblast-Dehuman fibroblast- } \\
\text { derived dermal substitute may offer } \\
\text { potential as a substitute to the connective } \\
\text { tissue graft for covering areas of facial Miller } \\
\text { Class I or Class II gingival recession in } \\
\text { humans derived dermal substitute may offer } \\
\text { potential as a substitute to the connective } \\
\text { tissue graft for covering areas of facial Miller } \\
\text { Class I or Class II gingival recession in } \\
\text { humans. }\end{array}$ \\
\hline McGuire et al. [19] & $\begin{array}{l}\text { Split mouth } \\
\text { case control } \\
\text { clinical trial }\end{array}$ & $\begin{array}{l}25 \text { patients with insufficient attached } \\
\text { gingiva associated with at least two teeth } \\
\text { in contra lateral quadrants of the same jaw } \\
\text { were treated. } \\
\text { control teeth: GA test teeth: HF-DDS graft }\end{array}$ & $\begin{array}{l}\text { Control group exhibited an average of } \\
1.0 \text { to } 1.2 \mathrm{~mm} \text { more keratinized tissue } \\
\text { over time and about half as much } \\
\text { shrinkage than the test group } \\
\text { Test sites demonstrated significantly } \\
\text { better color match and better, tissue } \\
\text { texture over time compared to control } \\
\text { sites. }\end{array}$ & $\begin{array}{l}\text { The tissue engineered HF-DDS graft was } \\
\text { safe and capable of generating keratinized } \\
\text { tissue without the morbidity and potential } \\
\text { clinical difficulties associated with donor site } \\
\text { surgery. } \\
\text { Test graft generated tissue that appeared } \\
\text { more natural. }\end{array}$ \\
\hline
\end{tabular}

Table 4: Fibroblast derived dermal substitute.

keratinized oral soft tissue. Moreover, GINTUIT generated gingival tissue that better matched the color and texture of the patients' surrounding tissue versus traditional palatal grafting procedures. Importantly, patients overwhelmingly preferred GINTUIT over the grafting procedure when taking into consideration all aspects of treatment (surgery, recovery, appearance). In clinical trials, GINTUIT was considered safe and well tolerated. GINTUIT is indicated for topical (non-submerged) application to a surgically created vascular wound bed in the treatment of mucogingival conditions in adults but is not intended to provide root coverage [21].

\section{Dermagraft}

It is composed of cryopreserved human-derived fibroblasts and collagen applied to a bioabsorbable mesh. Dermagraft was developed by Advanced Tissue Sciences and has been approved by the FDA for repair of diabetic foot ulcers and for use in the treatment of wounds related to dystrophic epidermolysis bullosa. The use of tissue-engineered dermal replacement in the vestibular extension instead of palatal donor tissue or (split-thickness) skin graft has been described in a recent study. In three patients the living human-derived Dermagraft was implanted on the wound surface after mucogingival junction and supraperiosteal dissection. Following application of Dermagraft, vestibular depth was increased and no scarring occurred. Tissue engineered dermal replacement consisting of living human fibroblasts has proved to be a useful substitute for autogenous grafts in pre prosthetic surgery, offering the advantage of unlimited availability, good colour match and no donor site morbidity [22].

\section{Aongen $^{\text {tm }}$}

Aongen $^{\text {tw }}$ by Body Organ Biomedical Corporation is a collagen based tissue repair and bone graft augmentation material. It is a bioabsorbable 3D matrix made of Type-I atelocollagen which is designed for successful soft tissue regeneration and stimulation of dental bone proliferation at an accelerated rate. Aongen ${ }^{\mathrm{n}}$ Dental is indicated for application as an aid in the management of extraction sockets, periodontal defects, bridges, dentures, implants, sinus lift osteotomies, soft tissue augmentation and 
oral wounds such as oral ulcers, denture sores and trauma or surgical wounds $[23,24]$. The porous structure of Aongen ${ }^{\text {tw }}$ Dental provides an ideal scaffold and interface for space maintenance, allowing the surrounding cells to seed and proliferate $[24,25]$. The matrix not only enhances the hemostasis process, but also stimulates and modulates the migration and proliferation of cells. Aongen ${ }^{\mathrm{nt}}$ Dental is absorbed within 30 days without adverse effects or production of any toxic substances. At the implant site, the course of action may persist for a longer duration depending on the characteristics of the stressed site and the predetermined remodeling mechanisms. It does not require prior preparation to best achieve its singular heal-expansive effects. The bullet and tape shapes allow uncomplicated placing at the insertion site. To prevent dislodgement at the site of placement, it can be trimmed and left in situ, suturing by peripheral gingival-soft tissue borders, or by other means. In terms of regeneration, it acts as a natural biological matrix designed to provide an excellent healing environment and acts as a guide for the regeneration of vital soft and bone tissue [25].

\section{Few Products that have a Potential to be used as a Dental Constructs}

\section{Apligraf (Organogenesis)}

It is a bilayered living cell therapy composed of an epidermal layer of living human keratinocytes and a dermal layer of living human fibroblasts. Apligraf is supplied as needed, in one size, with a shelf-life of 10 days. It was FDA-approved in 1998 for use in conjunction with compression therapy for the treatment of non-infected, partial- and full-thickness skin ulcers [26].

\section{OrCel $^{\mathrm{mw}}$ (Forticell Bioscience)}

It is formerly called Composite Cultured Skin. It is an absorbable allogeneic bi-layered cellular matrix, made of bovine collagen, in which human dermal cells have been cultured. It was approved by the FDA premarket approval (PMA) for healing donor site wounds in burn victims and under a humanitarian device exemption (HDE) for use in patients with recessive dystrophic epidermolysis bullosa undergoing hand reconstruction surgery to close and heal wounds created by the surgery, including those at donor sites.

\section{Epicel' (Genzyme Biosurgery)}

It is a cultured epithelial autograft and is FDA-approved under a humanitarian device exemption (HDE) for the treatment of deep dermal or full-thickness burns comprising a total body surface area of greater than or equal to $30 \%$. It may be used in conjunction with split-thickness autografts, or alone in patients for whom split-thickness autografts may not be an option due to the severity and extent of their burns. A study by of the Baltimore Regional Burn Center of the Johns Hopkins University compared the outcomes of therapy in patients with massive burns with or without cultured epidermal autografts (CEAs). There was found to be a significant reduction in mortality in the CEA group compared with controls, from $48 \%$ to $14 \%(\mathrm{p}<0.007)$ [27].

\section{Integra Dermal Regeneration Template (Integra LifeSciences)}

It is a bovine, collagen/glycosaminoglycan dermal replacement covered by a silicone temporary epidermal substitute. Integra Dermal Regeneration Template is an advanced skin replacement system, designed to provide immediate wound closure and permanent regeneration of the dermis. The product is placed in direct contact with the excised wound and consists of a complex three-dimensional porous matrix that acts as a scaffold for cell migration and allows for regeneration of the dermal layer of the patient's skin. It is FDAapproved for use in post excisional treatment of life-threatening fullthickness or deep partial-thickness thermal injury where sufficient autograft is not available at the time of excision or not desirable because of the physiologic condition of the patient. Integra ${ }^{\text {ma }}$ Matrix Wound Dressing and Integra ${ }^{\text {Tu }}$ meshed Bilayer Wound Matrix are substantially equivalent skin substitutes that are FDA-510(k) approved for other indications. No clinical trial by any institute has been conducted on this product yet.

\section{TransCyte" (Advanced Tissue Sciences)}

It consists of human dermal fibroblasts grown on nylon mesh of Biobrane combined with a synthetic epidermal layer and was approved by the FDA in 1997. TransCyte is intended to be used as a temporary covering over burns until autografting is possible. It can also be used as a temporary covering for some burn wounds that heal without autografting. A prospective, randomized, comparison study of silver sulfadiazine and TransCyte was performed with the use of paired wound sites on 14 patients to evaluate the role of TransCyte for the treatment of partial-thickness burns. Wounds treated with TransCyte healed more quickly (mean 11.14 days to $90 \%$ epithelialization vs 18.14 days, $\mathrm{p}=0.002$ ). A non-comparison evaluation was then done for an additional 18 patients, and it confirmed excellent wound healing and an absence of infections. There were no infections in the 32 wound sites treated with TransCyte. In the first study group, late wound evaluations (3, 6, and 12 months postburn) were performed with use of the Vancouver Scar Scale. The results indicated that wound sites treated with TransCyte healed with less hypertrophic scarring than sites treated with silver sulfadiazine $(\mathrm{p}<0.001$ at 3 and 6 months, $\mathrm{p}=0.006$ at 12 months) [28]. Similar results were obtained in another prospective study [29].

\section{OASIS $^{\text {ma }}$ Wound Matrix (Cook Biotech)}

It is a xenogeneic collagen scaffold derived from porcine small intestinal mucosa. It was cleared by the FDA's $510(\mathrm{k})$ process in 2000 for the management of partial and full-thickness wounds including pressure ulcers, venous ulcers, diabetic ulcers, chronic vascular ulcers, tunneled undermined wounds, surgical wounds, trauma wounds, and draining wounds. A prospective, randomized, controlled multicenter trial was conducted with the objective of comparing the effectiveness of OASIS wound matrix with compression vs. compression alone in healing chronic leg ulcers within 12 weeks. 120 patients with at least 1 chronic leg ulcer were randomly assigned to receive either weekly topical treatment of OASIS plus compression therapy $(n=62)$ or compression therapy alone $(n=58)$. Ulcer size was determined at enrollment and weekly throughout the treatment. Healing was assessed weekly for up to 12 weeks. Recurrence after 6 months was recorded. The primary outcome measure was the proportion of ulcers healed in each group at 12 weeks. After 12 weeks of treatment, $55 \%$ of the wounds in the OASIS group were healed, as compared with $34 \%$ in the standard-care group $(\mathrm{p}=0.0196)$. None of the healed patients treated with OASIS wound matrix and observed for the 6-month follow-up experienced ulcer recurrence. Thus it was suggested that the SIS wound matrix, as an adjunct therapy, significantly improves healing of chronic leg ulcers over compression therapy alone [30].

\section{Conclusion}

Tissue engineered mucosal constructs owe their origin to the treatment of ulcers, diabetic foot, burns followed by an increasing interest in the field of dentistry too. Mucosal substitutes are made of cell sources that have not caused acute and chronic tissue reaction and 
have self-renewal properties that can re-grow and differentiate to a new tissue. Further, these mucosal substitutes can serve as biodegradable scaffolds and with the appropriate bioreactors, the quality of tissue may also be controlled. With all the advantages of reproducible tissue engineering technologies, these mucosal substitutes/oral mucosal equivalents appear to be the imminent hope for tissue repair, replacement or regeneration in regenerative medicine in the treatment of lost tissues, impaired functions and soft tissue defects that are caused by congenital abnormalities, trauma, diseases or aging processes.

\section{References}

1. American Academy of Periodontology (2001) Glossary of periodontal terms $\left(4^{\text {th }}\right.$ edn $)$, American Academy of Periodontology, Chicago.

2. Ophof R (2010) Construction and application of substitutes for oral mucosa in cleft palate repair (dissertation). Nijmegen Medical Center, Radboud University, the Netherlands.

3. Sanz M, Lorenzo R, Aranda JJ, Martin C, Orsini M (2009) Clinical evaluation of a new collagen matrix (Mucograft prototype) to enhance the width of keratinized tissue in patients with fixed prosthetic restorations: a randomized prospective clinical trial. J Cin Periodontol 36: 868-876.

4. Rotundo R, Pini-Prato G (2012) Use of a new collagen matrix (mucograft) for the treatment of multiple gingival recessions: case reports. Int J Periodontics Restorative Dent 32: 413-419.

5. Nocini PF, Zanotti G, Castellani R, Grasso S, Cristofaro MG, et al. (2013) Bi-layered collagen nano-structured membrane prototype (collagen matrix 10826(®)) for oral soft tissue regeneration: an "in vitro" study. Clin Oral Implants Res 24: 612-617.

6. Golinski PA, Gröger S, Herrmann JM, Bernd A, Meyle J (2011) Oral mucosa model based on a collagen-elastin matrix. J Periodontal Res 46: 704-711.

7. Shah R, Sowmya NK, Mehta DS (2014) Amnion membrane for coverage of gingival recession: A novel application. Contemp Clin Dent 5: 293-295.

8. Ghahroudi AA, Khorsand A, Rokn AR, Sabounchi SS, Shayesteh YS, et al. (2013) Comparison of amnion allograft with connective tissue graft for root coverage procedures: a double-blind, randomized, controlled clinical trial. J Int Acad Periodontol 15: 101-112.

9. Shetty SS, Chatterjee A, Bose S (2014) Bilateral multiple recession coverage with platelet-rich fibrin in comparison with amniotic membrane. J Indian Soc Periodontol 18: 102-106.

10. Sculean A, Schwarz F, Becker J, Brecx M (2007) The application of an ename matrix protein derivative (Emdogain) in regenerative periodontal therapy: a review. Med Princ Pract 16: 167-180.

11. Lyngstadaas SP, Lundberg E, Ekdahl H, Andersson C, Gestrelius S (2001) Autocrine growth factors in human periodontal ligament cells cultured on enamel matrix derivative. J Clin Periodontol 28: 181-188.

12. Jaiswal GR, Kumar R, Khatri PM, Jaiswal SG, Bhongade ML (2012) The effectiveness of enamel matrix protein (Emdogain ${ }^{\circledR}$ ) in combination with coronally advanced flap in the treatment of multiple marginal tissue recession: A clinical study. J Indian Soc Periodontol 16: 224-230.

13. Berlucchi I, Francetti L, Del Fabbro M, Testori T, Weinstein RL (2002) Ename matrix proteins (Emdogain) in combination with coronally advanced flap or subepithelial connective tissue graft in the treatment of shallow gingival recessions. Int J Periodontics Restorative Dent 22: 583-593.

14. Hägewald S, Spahr A, Rompola E, Haller B, Heijl L, et al (2002) Root coverage using Emdogain versus coronally advanced flap technique. J Clin Perodontol 29: $39-41$

15. Izumi K, Song J, Feinberg SE (2004) Development of a tissue-engineered human oral mucosa: from the bench to the bed side. Cells Tissues Organs 176: 134-152.

16. Izumi K, Neiva RF, Feinberg SE (2013) Intraoral grafting of tissue-engineered human oral mucosa. Int J Oral Maxillofac Implants 28: 295-303.

17. Mohammadi M, Mofid R, Shokrgozar MA (2011) Peri-implant soft tissue management through use of cultured gingival graft: a case report. Acta Med Iran 49: 319-324.

18. Wilson TG Jr, McGuire MK, Nunn ME (2005) Evaluation of the safety and efficacy of periodontal applications of a living tissue-engineered human fibroblast-derived dermal substitute. II. Comparison to the subepithelia connective tissue graft: a randomized controlled feasibility study. J Periodontol 76: 881-889.

19. McGuire MK, Nunn ME (2005) Evaluation of the safety and efficacy of periodontal applications of a living tissue-engineered human fibroblast-derived dermal substitute. I. Comparison to the gingival autograft: a randomized controlled pilot study. J Periodontol 76: 867-880.

20. Morelli T, Neiva R, Nevins ML, McGuire MK, Scheyer ET, et al. (2011) Angiogenic biomarkers and healing of living cellular constructs. J Dent Res 90: 456-462.

21. Organogenesis Cellular Technology (2012) http://www.organogenesis.com/ news/press-release-announces-03122012.html

22. Raguse JD, Gath HJ (2005) A metabolically active dermal replacement (Dermagraft) for vestibuloplasty. J Oral Rehabil 32: 337-340.

23. Lee $\mathrm{CH}$, Singla A, Lee $Y$ (2001) Biomedical applications of collagen. Int $J$ Pharm 221: 1-22.

24. Sclar AG (2004) Strategies for management of single-tooth extraction sites in aesthetic implant therapy. J Oral Maxillofac Surg 62: S 90-105.

25. Schropp L, Wenzel A, Kostopoulos L, Karring T (2003) Bone healing and soft tissue contour changes following Single tooth extraction: a clinical and radiographic 12-month prospective study. Int J Periodontics Restorative Dent 23: 313-323.

26. Zaulyanov L, Kirsner RS (2007) A review of a bi-layered living cell treatment (Apligraf) in the treatment of venous leg ulcers and diabetic foot ulcers. Clin Interv Aging 2: 93-98.

27. Munster AM (1996) Cultured skin for massive burns: a prospective, controlled trial. Ann Surg 224: 372-375.

28. Noordenbos J, Dore C, Hansbrough JF (1999) Safety and efficacy of TransCyte for the treatment of partial-thickness burns. J Burn Care Rehabil 20: 275-281.

29. Kumar RJ, Kimble RM, Boots R, Pegg SP (2004) Treatment of partial-thickness burns: a prospective, randomized trial using transcyte. Anz J Surg 74: 622-626.

30. Mostow EN, Haraway GD, Dalsing M, Hodde JP, King D (2005) Effectiveness of an extracellular matrix graft (OASIS Wound Matrix) in the treatment of chronic leg ulcers: A randomized clinical trial. J Vasc Surg 41: 837-843. 